\title{
Reply to: Shark mortality cannot be assessed by fishery overlap alone
}

https://doi.org/10.1038/s41586-021-03397-3

Check for updates

\begin{abstract}
Nuno Queiroz ${ }^{1,2}$, Nicolas E. Humphries ${ }^{2}$, Ana Couto', Marisa Vedor ${ }^{1,3}$, Ivo da Costa', Ana M. M. Sequeira ${ }^{4,5}$, Gonzalo Mucientes', António M. Santos ${ }^{1,3}{ }^{1}$ Francisco J. Abascal $^{6}$, Debra L. Abercrombie ${ }^{7}$, Katya Abrantes ${ }^{8}$, David Acuña-Marrero ${ }^{9}$, André S. Afonso ${ }^{10,11}$, Pedro Afonso ${ }^{12,13,14}$, Darrell Anders ${ }^{15}$, Gonzalo Araujo ${ }^{16}$, Randall Arauz ${ }^{17,18,19}$, Pascal Bach ${ }^{20}$, Adam Barnett ${ }^{8}$, Diego Bernal ${ }^{21}$, Michael L. Berumen ${ }^{22}$, Sandra Bessudo Lion ${ }^{19,23}$, Natalia P. A. Bezerra ${ }^{10}$, Antonin V. Blaison ${ }^{20}$, Barbara A. Block ${ }^{24}$, Mark E. Bond ${ }^{25}$, Ramon Bonfil $^{26}$, Russell W. Bradford ${ }^{27}$, Camrin D. Braun ${ }^{28,29}$, Edward J. Brooks ${ }^{30}$, Annabelle Brooks ${ }^{30,31}$, Judith Brown ${ }^{32}$, Barry D. Bruce ${ }^{27}$, Michael E. Byrne ${ }^{33,34}$, Steven E. Campana ${ }^{35}$, Aaron B. Carlisle ${ }^{36}$, Demian D. Chapman ${ }^{25}$, Taylor K. Chapple ${ }^{24}$, John Chisholm ${ }^{37}$, Christopher R. Clarke ${ }^{38}$, Eric G. Clua ${ }^{39}$, Jesse E. M. Cochran ${ }^{22}$, Estelle C. Crochelet ${ }^{40,41}$, Laurent Dagorn ${ }^{20}$, Ryan Daly ${ }^{42,43}$, Daniel Devia Cortés ${ }^{44}$, Thomas K. Doyle ${ }^{45,46}$, Michael Drew ${ }^{47}$, Clinton A. J. Duffy ${ }^{48}$, Thor Erikson ${ }^{49}$, Eduardo Espinoza ${ }^{19,50}$, Luciana C. Ferreira ${ }^{51}$, Francesco Ferretti ${ }^{52}$, John D. Filmalter ${ }^{20,43}$, G. Chris Fischer ${ }^{53}$, Richard Fitzpatrick ${ }^{8}$, Jorge Fontes ${ }^{12,13,14}$, Fabien Forget ${ }^{20}$, Mark Fowler ${ }^{54}$, Malcolm P. Francis ${ }^{55}$, Austin J. Gallagher ${ }^{56,57}$, Enrico Gennari ${ }^{42,58,59}$, Simon D. Goldsworthy ${ }^{60}$, Matthew J. Gollock ${ }^{61}$, Jonathan R. Green ${ }^{62}$, Johan A. Gustafson ${ }^{63}$, Tristan L. Guttridge ${ }^{64}$, Hector M. Guzman ${ }^{65}$, Neil Hammerschlag ${ }^{57,66}$, Luke Harman ${ }^{45}$, Fábio H. V. Hazin ${ }^{10}$, Matthew Heard ${ }^{47}$, Alex R. Hearn ${ }^{19,67,68}$, John C. Holdsworth ${ }^{69}$, Bonnie J. Holmes ${ }^{70}$, Lucy A. Howey ${ }^{71}$, Mauricio Hoyos ${ }^{19,72}$, Robert E. Hueter ${ }^{73}$, Nigel E. Hussey ${ }^{74}$, Charlie Huveneers $^{47}$, Dylan T. Irion ${ }^{75}$, David M. P. Jacoby ${ }^{76}$, Oliver J. D. Jewell ${ }^{77,78}$, Ryan Johnson ${ }^{79}$, Lance K. B. Jordan ${ }^{71}$, Warren Joyce ${ }^{54}$, Clare A. Keating Daly ${ }^{42}$, James T. Ketchum ${ }^{19,72}$, A. Peter Klimley ${ }^{19,80}$, Alison A. Kock ${ }^{43,81,82,83}$, Pieter Koen ${ }^{84}$, Felipe Ladino ${ }^{23}$, Fernanda O. Lana ${ }^{85}$, James S. E. Lea ${ }^{38,86}$, Fiona Llewellyn ${ }^{61}$, Warrick S. Lyon ${ }^{55}$, Anna MacDonnell ${ }^{54}$, Bruno C. L. Macena ${ }^{10,13}$, Heather Marshall ${ }^{21,87}$, Jaime D. McAllister ${ }^{88}$, Michael A. Meÿer ${ }^{15}$, John J. Morris ${ }^{73}$, Emily R. Nelson ${ }^{57}$, Yannis P. Papastamatiou ${ }^{25}$, Cesar Peñaherrera-Palma ${ }^{19,89}$, Simon J. Pierce ${ }^{90}$, Francois Poisson ${ }^{20}$, Lina Maria Quintero ${ }^{23}$, Andrew J. Richardson ${ }^{91}$, Paul J. Rogers ${ }^{60}$, Christoph A. Rohner ${ }^{90}$, David R. L. Rowat ${ }^{92}$, Melita Samoilys $^{93}$, Jayson M. Semmens ${ }^{88}$, Marcus Sheaves ${ }^{8}$, George Shillinger ${ }^{19,24,94}$,

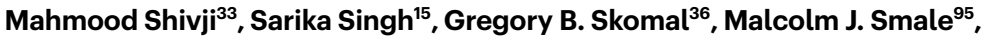
Laurenne B. Snyders ${ }^{15}$, German Soler ${ }^{19,23,88}$, Marc Soria ${ }^{20}$, Kilian M. Stehfest ${ }^{88}$, Simon R. Thorrold ${ }^{29}$, Mariana T. Tolotti ${ }^{20}$, Alison Towner ${ }^{59,78}$, Paulo Travassos ${ }^{10}$, John P. Tyminski ${ }^{73}$, Frederic Vandeperre ${ }^{12,13,14}$, Jeremy J. Vaudo ${ }^{33}$, Yuuki Y. Watanabe ${ }^{96,97}$, Sam B. Weber ${ }^{98}$, Bradley M. Wetherbee ${ }^{33,99}$, Timothy D. White ${ }^{24}$, Sean Williams ${ }^{30}$, Patricia M. Zárate ${ }^{100}$, Robert Harcourt ${ }^{101}$, Graeme C. Hays ${ }^{102}$, Mark G. Meekan ${ }^{51}$, Michele Thums ${ }^{51}$, Xabier Irigoien ${ }^{103,104}$, Victor M. Eguiluz ${ }^{105}$, Carlos M. Duarte ${ }^{22}$, Lara L. Sousa ${ }^{2,106}$, Samantha J. Simpson ${ }^{2,107}$, Emily J. Southall ${ }^{2}$ \& David W. Sims ${ }^{2,107,108 \bowtie}$
\end{abstract}

REPLYING TO H. Murua et al. Nature https://doi.org/10.1038/s41586-021-03396-4 (2021)
Our previously published paper $^{1}$ provided global fine-scale spatiotemporal estimates $\left(1^{\circ} \times 1^{\circ} ;\right.$ monthly $)$ of overlap and fishing exposure risk (FEI) between satellite-tracked shark space use and automatic identification system (AIS) longline fishing effort. We did not assess shark mortality directly, but in addition to replying to the Comment by Murua et al. ${ }^{2}$, we confirm-using regression analysis of spatially matched data-that fishing-induced pelagic shark mortality (catch per unit effort (CPUE)) is greater where FEI is higher.

We focused on assessing shark horizontal spatiotemporal overlap and exposure risk with fisheries because spatial overlap is a major driver of fishing capture susceptibility and previous shark ecological risk assessments (ERAs) assumed a homogenous shark density within species-range distributions ${ }^{3-5}$ or used coarse-scale modelled occurrence data, rather than more ecologically realistic risk estimates in heterogeneous habitats that were selected by sharks over time. Furthermore, our shark spatial exposure risk implicitly accounts for other susceptibility factors with equal or similar probabilities to those commonly used in shark ERAs ${ }^{3,5}$.

First, actual depth distributions are seldom incorporated in shark ERAs and full vertical overlap with an encounterability probability of one is often applied ${ }^{3,5}$. This is an implicit assumption in our FEI as the pelagic species that we tracked exhibit vertical movements that overlap with depths of pelagic longlines (for example, $18-267 \mathrm{~m}$ ) ${ }^{6}$ during both the day and night ${ }^{7}$. Second, we account for selectivity by focusing our fisheries-independent spatial estimates directly on individuals that were actually caught by the focal fisheries. The majority of the 1,804 
a - Shark relative density hotspots FEl Whigh levels of fishing effort
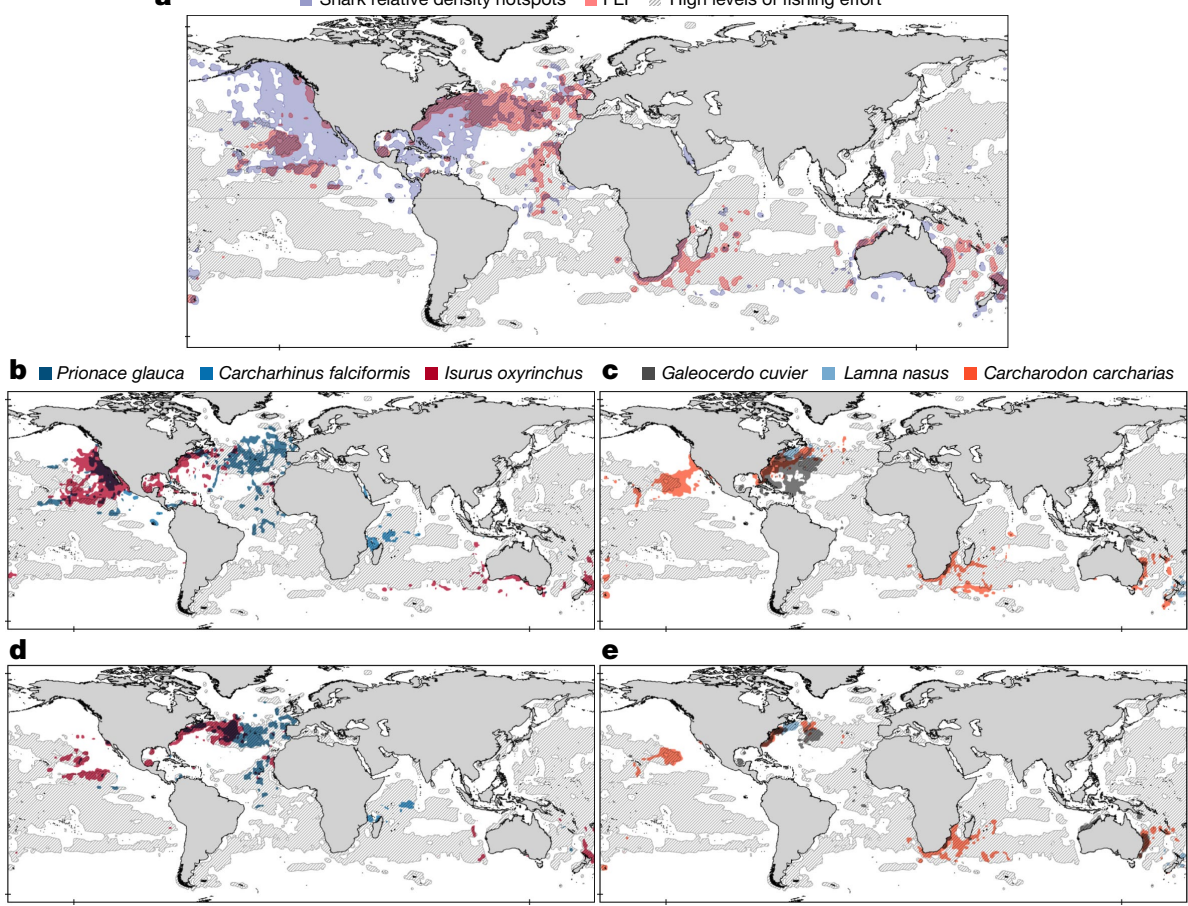

Fig. 1 | Spatial distributions and overlap of sharks and longline fishing vessels. a, Shark relative density hotspots ( $>75$ th percentile) and FEI hotspots ( $>75$ th percentile) overlaid on high longline fishing effort (higher than average; $>50$ th percentile) at the $1^{\circ} \times 1^{\circ}$ grid size to illustrate the degree of overlap between the different drivers of FEI hotspots. Higher than average fishing effort is used here to reflect a major driver of FEI hotspots as FEI hotspots do not arise solely as a result of shark density hotspots overlapping with fishing effort hotspots ( $>75$ th percentile), the metric used by Murua et al. ${ }^{2}$. b-e, Relative density hotspots (b, c) and FEI hotspots $(\mathbf{d}, \mathbf{e})$ for six shark species overlaid on high longline fishing effort. Data are from our original paper' ${ }^{1}$. sharks tagged were caught on commercial-type longline hooks before release. This is equivalent to a selectivity probability of around one as used in shark ERAs ${ }^{5}$. Third, the commercially valuable sharks that we tracked are seldom discarded by major high-seas longlining fleets ${ }^{8}$, indicating that an implicit assumption of a fishing mortality probability of one does not substantially overestimate the mortality that occurs. Murua et al. ${ }^{2}$ overlook that fact that although some species with fishing prohibitions (such as silky and great hammerhead sharks) may be released alive, reported hooking mortalities are high (for example, $56 \%$ for silky sharks and $96 \%$ for great hammerhead sharks) $)^{9,10}$ in addition to at least around $50 \%$ post-release mortality ${ }^{11,12}$. Collectively, this indicates 78-98\% total mortality even of prohibited species. The similar assumptions between our analyses and previous assessments result in comparable susceptibility estimates that will not alter our FEl. For example, we estimated that shortfin mako, blue and porbeagle sharks as the highest exposure risk species in the North Atlantic, which were also the shark species with the highest estimated susceptibilities to longline fishing in a recent Atlantic shark ERA ${ }^{4}$.

Regarding FEI being related to fishing-induced shark mortality, we stated $^{1}$ that the significant positive relationship between Food and Agriculture Organization (FAO) fishery landings data and individual-species mean FEI "implies that the index reflects fishing-induced shark mortality". Our conclusion was appropriately cautious because we recognized that FAO landings data were limited in quality, aggregated at regional scales and subject to high levels of unreported or underreported data ${ }^{13}$, and are potentially unrelated to shark relative abundances. Murua et al. ${ }^{2}$ confirm the result presented in our paper and also show nine further data combinations that we did not test resulting in eight non-significant positive relationships. However, having few data points $(n=8$ species per test) when comparing the spatial complexity of FEI $\left(1^{\circ} \times 1^{\circ}\right.$ grid $)$ to non-spatially explicit FAO datasets-given the high variability in the quality of landings data-biases results towards non-significance. To address this, we tested linear-regression models for spatially matched data, including longline CPUE (a relative measure of abundance) of pelagic sharks as the response variable and $\mathrm{FEI}$, fishing effort and number of longline sets as explanatory variables, including interactions with year or month (Supplementary Information). The best model when testing interactions with month was for fishing effort (Akaike information criterion weights $($ WAIC $)=1$ ), but the deviance explained was similar between this model (46\%) and those models that included FEI (42\%) or the number of sets $(43 \%)$. When testing interactions with year, the best model was FEI (WAIC $=0.89$ ), showing a significant and positive relationship with CPUE $\left(n=523, r^{2}=0.11, F_{9,513}=7.17, P<0.0001\right)$. Bootstrapping tests randomly by removing $1-25 \%$ of data confirmed that the best model alternates between fishing effort and FEI as an explanatory variable of shark CPUE. For spatially matched data, therefore, pelagic shark CPUE is significantly greater in areas in which FEI is higher and is as good an explanatory variable of CPUE as fishing effort itself, corroborating our previously published result ${ }^{1}$ that $\mathrm{FEI}$ reflects fishing-induced shark mortality.

Using spatial exposure risk plots between overlap and FEI to indicate higher or lower than average exposure risk (that is, potential capture susceptibility) is not misleading because the categorization relates specifically to areas in which shark species were tracked and overlap with fishing effort occurred. We previously showed ${ }^{1}$ the FEI maps alongside the exposure risk plots to make this point clear. Higher exposure risk can be driven by high FEI when it occurs in specific space-use areas, even if spatial overlap appears relatively low in a region (for example, for white sharks in Oceania). Correct interpretation of our exposure risk estimates requires reference to the areas over which shark hotspots and fishing effort occurred.

FEI hotspots driven by shark hotspots in large-scale ocean ecosystems (for example, the Gulf Stream) led us to conclude that high levels of fishing effort are focused on extensive hotspots of shark space use ${ }^{1}$. Murua et al. ${ }^{2}$ generate a new metric (fishing effort hotspots, $>75$ th percentile) to conclude that shark hotspots are not related to main fishing 

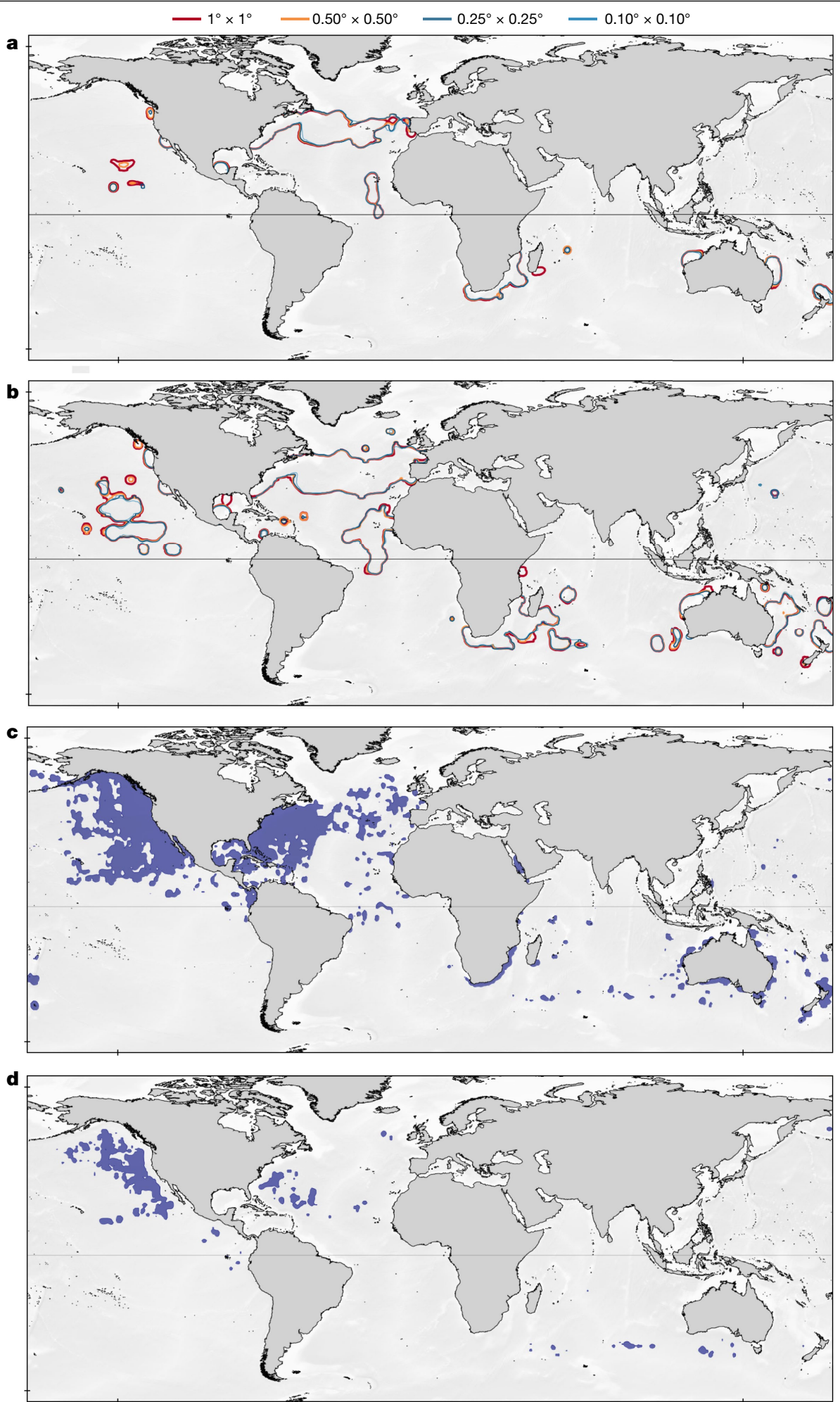

Fig. 2 | Effect of scale on the position and extent of FEI hotspots and areas free from AIS longline fishing effort. $\mathbf{a}, \mathbf{b}$, The position and extent of FEI hotspots at the $>90$ th percentile (a) and $>75$ th percentile (b) of the mean FEI do not substantially change across four grid cell sizes from $1^{\circ} \times 1^{\circ}$ to $0.1^{\circ} \times 0.1^{\circ}$. c, d, Global distribution of the shark relative density hotspots estimated from

effort areas. However, we did not calculate fishing effort hotspots nor relate them to shark density hotspots or FEI hotspots because this approach ignores key drivers of FEI hotspots (see below) and is selective of available data. We did not equate high levels of fishing effort solely to fishing effort hotspots because sharks are often caught and retained by satellite locations (c) and the shark hotspots where there was no recorded AIS longline fishing effort (2012-2016) in ABNJs, the high seas (d). d, Data from Global Fishing Watch (https://globalfishingwatch.org/). This supports our original conclusion that pelagic sharks have limited spatial refuge from the current levels of fishing effort in ABNJs.

fishing vessels that did not specifically target sharks, so shark relative density or FEI hotspots should not be expected to correctly predict fishing effort hotspots in the majority of cases. Rather, we showed that FEI hotspots arise from shark relative density hotspots, high fishing effort levels (not only the highest fishing effort levels considered by 
Murua et al. ${ }^{2}$ ), a combination of both, and some ( $\left.<2 \%\right)$ are driven by lower shark densities or fishing intensities (Extended Data Table 1).

Consistent with our conclusion, vast areas with higher-than-average fishing effort extend across major shark density and FEI hotspots (Fig. 1). For example, FEI hotspots overlap with shark density hotspots in $56 \%$ of grid cells globally, and overlap with higher-than-average fishing effort in $81 \%$ of grid cells (Fig. 1). That shark density hotspots and higher-than-average fishing effort together drive $39 \%$ of FEI hotspots supports our original conclusion. This is even more clearly seen for individual species (Fig. 1b-e and Extended Data Table 2). For example, globally, blue shark hotspots and high fishing effort together drive $50 \%$ of blue shark FEI hotspots (Fig. 1b, d) and, regionally, white shark hotspots and high fishing effort in the northeast Pacific together drive $67 \%$ of FEI hotspots (Fig. 1c, e). The claim by Murua et al. ${ }^{2}$ that shark hotspots are not related to main fishing effort areas is not supported when all drivers of FEI hotspots are considered.

Furthermore, large reductions in grid cell size do not affect FEI hotspots. We previously provided results showing, as expected, that reductions from $2 \times 2^{\circ}$ to $0.1 \times 0.1^{\circ}$ lowers absolute overlap and FEI values but relative exposure-risk plots remain unchanged (extended data figure 4 and supplementary figure 4 of ref. ${ }^{1}$ ). It is possible that our results and conclusions could be affected if the spatial positions and extent of FEI hotspots-indicating potential changes in relative drivers that affect overlap and FEI estimates (see above)-were substantially altered as the size of the grid cells decreases. However, the position and extent of FEI hotspots remain largely unchanged as grid size decreases (Fig. 2a, b), indicating that the results and conclusions concerning FEI hotspots are highly unlikely to be affected.

Lastly, we disagree that our analyses do not support our conclusion of limited spatial refuge for pelagic sharks from current levels of fishing effort in Areas Beyond National Jurisdictions (ABNJs). Globally, only about one third of $A B N J$ shark hotspot grid cells were free from AIS-tracked longline fishing effort, indicating that fishing effort overlapped with the majority of shark hotspots (Fig. 2c, $d$ and Extended Data Table 3). Some heavily fished regions showed even lower levels of spatial refuge, only $13 \%$ and $20 \%$ of Indian Ocean and North Atlantic shark hotspot grid cells, respectively, were free from fishing effort. Hotspots are areas of preferred habitat where sharks spent most time ${ }^{1}$, thus it was justified to conclude that for the results presented there was limited spatial refuge in ABNJs. The percentage of spatial refuge for sharks in $\mathrm{ABNJs}$ decreases to $<25 \%$ of shark relative density hotspots when additional AIS data that were not previously available are included (Extended Data Table 4), indicating that our original spatial refuges were actually overestimated.

In summary, we think that the arguments presented neither call into question our results and conclusions nor misdirect management efforts as our exposure risk estimates are spatially and temporally explicit. We do not dispute that regional fishery management organizations for tuna have put management measures in place; these were described in our paper ${ }^{1}$. Nevertheless, pelagic sharks have declined globally over many decades ${ }^{13-15}$, strongly indicating that additional measures are still required to conserve populations effectively, including more complete data reporting, catch quotas and greater enforcement ${ }^{13,15}$. The data and analyses in our paper ${ }^{1}$ contribute to this goal. Indeed, regional fishery management organizations for tuna state that data on biologically important areas, spatiotemporal distributions of shark stocks and interactions with fishing fleets ${ }^{8}$ are needed to aid management. We have provided a first step by making available fishery-independent data ${ }^{1}$ on shark spatial density and hotspot locations to complement current assessment approaches.

\section{Reporting summary}

Further information on experimental design is available in the Nature Research Reporting Summary linked to this paper.

\section{Data availability}

Data used in linear-regression modelling are available on GitHub (https:// github.com/GlobalSharkMovement/GlobalSpatialRisk/derived_data/). Data used to prepare the maps (shark relative spatial density, longlinefishing effort and shark-longline-fishing overlap and FEI) are available on GitHub (https://github.com/GlobalSharkMovement/Global SpatialRisk).

\section{Code availability}

Code used to prepare the maps (shark relative spatial density, longline-fishing effort and shark-longline-fishing overlap and FEI) is available on GitHub (https://github.com/GlobalSharkMovement/ GlobalSpatialRisk).

1. Queiroz, N. et al. Global spatial risk assessment of sharks under the footprint of fisheries. Nature 572, 461-466 (2019).

2. Murua, H. et al. Shark mortality cannot be assessed by fishery overlap alone. Nature https://doi.org/10.1038/s41586-021-03396-4 (2021).

3. Cortés, E. et al. Ecological risk assessment of pelagic sharks caught in Atlantic pelagic longline fisheries. Aquat. Living Resour. 23, 25-34 (2010).

4. Cortés, E. et al. Expanded ecological risk assessment of pelagic sharks caught in Atlantic pelagic longline fisheries. Collect. Vol. Sci. Pap. ICCAT 71, 2637-2688 (2015).

5. Murua, H. et al. Updated Ecological Risk Assessment (ERA) for shark species caught in fisheries managed by the Indian Ocean Tuna Commission (IOTC). 21st Meeting of the Scientific Committee of the IOTC Document IOTC-2018-SC21-14 (Indian Ocean Tuna Commission, 2018).

6. Ward, P. \& Myers, R. A. Inferring the depth distribution of catchability for pelagic fishes and correcting for variations in the depth of longline fishing gear. Can. J. Fish. Aquat. Sci. 62, 1130-1142 (2005).

7. Andrzejaczek, S., Gleiss, A. C., Pattiaratchi, C. B. \& Meekan, M. G. Patterns and drivers of vertical movements of the large fishes of the epipelagic. Rev. Fish Biol. Fish. 29, 335-354 (2019).

8. International Commission for the Conservation of Atlantic Tunas. Report of the 2018 ICCAT Intersessional Meeting of the Sharks Species Group (2018).

9. Coelho, R., Fernandez-Carvalho, J., Lino, P. G. \& Santos, M. N. An overview of the hooking mortality of elasmobranchs caught in a swordfish pelagic longline fishery in the Atlantic Ocean. Aquat. Living Resour. 25, 311-319 (2012).

10. Dapp, D. R., Walker, T. I., Huveneers, C. \& Reina, R. D. Respiratory mode and gear type are important determinants of elasmobranch immediate and post-release mortality. Fish Fish. 17, 507-524 (2016)

11. Gallagher, A. J., Serafy, J. E., Cooke, S. J. \& Hammerschlag, N. Physiological stress response, reflex impairment, and survival of five sympatric shark species following experimental capture and release. Mar. Ecol. Prog. Ser. 496, 207-218 (2014).

12. Hutchinson, M. R., Itano, D. G., Muir, J. A. \& Holland, K. N. Post-release survival of juvenile silky sharks captured in a tropical tuna purse seine fishery. Mar. Ecol. Prog. Ser. 521, 143-154 (2015).

13. Worm, B. et al. Global catches, exploitation rates, and rebuilding options for sharks. Mar. Policy 40, 194-204 (2013).

14. McCauley, D. J. et al. Marine defaunation: animal loss in the global ocean. Science 347, 1255641 (2015).

15. Pacoureau, N. et al. Half a century of global decline in oceanic sharks and rays. Nature 589, 567-571 (2021).

Acknowledgements Funding support was provided by the Natural Environment Research Council (NERC) (NE/RO0997/X/1), European Research Council (ERC-AdG-2019 883583 OCEAN DEOXYFISH) (D.W.S.), Fundação para a Ciência e a Tecnologia CEECIND/02857/2018 (N.Q.) and PTDC/BIA-COM/28855/2017 (M.V.). This research is part of the Global Shark Movement Project (https://www.globalsharkmovement.org/).

Author contributions N.Q. and D.W.S. planned the data analysis. N.Q. led the data analysis with contributions from M.V., A.M.M.S. and D.W.S. N.E.H. contributed analysis tools. A.M.M.S. undertook linear-regression modelling. D.W.S. led the manuscript writing with contributions from N.Q., N.E.H., A.M.M.S and all authors. Six of the original authors were not included in the Reply authorship; two authors retired from science and the remaining four, although supportive of our Reply, declined to join the authorship due to potential conflicts of interest with the authors of the Comment and/or their institutions.

Competing interests The authors declare no competing interests.

\section{Additional information}

Supplementary information The online version contains supplementary material available at https://doi.org/10.1038/s41586-021-03397-3.

Correspondence and requests for materials should be addressed to D.W.S.

Reprints and permissions information is available at http://www.nature.com/reprints. Publisher's note Springer Nature remains neutral with regard to jurisdictional claims in published maps and institutional affiliations.

(c) The Author(s), under exclusive licence to Springer Nature Limited 2021 
${ }^{1}$ Centro de Investigação em Biodiversidade e Recursos Genéticos/Research Network in Biodiversity and Evolutionary Biology, Campus Agrário de Vairão, Universidade do Porto, Vairão, Portugal. ${ }^{2}$ Marine Biological Association of the United Kingdom, Plymouth, UK ${ }^{3}$ Departamento de Biologia, Faculdade de Ciências da Universidade do Porto, Porto, Portugal. ${ }^{4}$ UWA Oceans Institute, Indian Ocean Marine Research Centre, University of Western Australia, Crawley, Western Australia, Australia. ${ }^{5}$ School of Biological Sciences, University of Western Australia, Crawley, Western Australia, Australia. ${ }^{6}$ Spanish Institute of Oceanography, Santa Cruz de Tenerife, Spain. ${ }^{7}$ Abercrombie and Fish, Port Jefferson Station, NY, USA. ${ }^{8}$ Marine Biology and Aquaculture Unit, College of Science and Engineering, James Cook University, Cairns, Queensland, Australia. ${ }^{9}$ Institute of Natural and Mathematical Sciences, Massey University, Palmerston North, New Zealand. ${ }^{10}$ Universidade Federal Rural de Pernambuco (UFRPE), Departamento de Pesca e Aquicultura, Recife, Brazil. ${ }^{11} \mathrm{MARE}$, Marine and Environmental Sciences Centre, Instituto Politécnico de Leiria, Peniche, Portugal. ${ }^{12}$ MARE, Laboratório Marítimo da Guia, Faculdade de Ciências da Universidade de Lisboa, Cascais, Portugal. ${ }^{13}$ Institute of Marine Research (IMAR), Departamento de Oceanografia e Pescas, Universidade dos Açores, Horta, Portugal. ${ }^{14}$ Okeanos Departamento de Oceanografia e Pescas, Universidade dos Açores, Horta, Portugal. ${ }^{15}$ Department of Environmental Affairs, Oceans and Coasts Research, Cape Town, South Africa. ${ }^{16}$ Large Marine Vertebrates Research Institute Philippines, Jagna, Philippines. ${ }^{17}$ Fins Attached Marine Research and Conservation, Colorado Springs, CO, USA. ${ }^{18}$ Programa Restauración de Tortugas Marinas PRETOMA, San José, Costa Rica. ${ }^{19}$ MigraMar, Olema, CA, USA. ${ }^{20}$ Institut de Recherche pour le Développement, UMR MARBEC (IRD, Ifremer, Univ Montpellier, CNRS), Sète, France. ${ }^{21}$ Biology Department, University of Massachusetts Dartmouth, Dartmouth, MA, USA. ${ }^{22}$ Red Sea Research Center, Division of Biological and Environmental Science and Engineering, King Abdullah University of Science and Technology, Thuwal, Saudi Arabia. ${ }^{23}$ Fundación Malpelo y Otros Ecosistemas Marinos, Bogota, Colombia. ${ }^{24} \mathrm{Hopkins}$ Marine Station of Stanford University, Pacific Grove, CA, USA. ${ }^{25}$ Department of Biological Sciences, Florida International University, North Miami, FL, USA. ${ }^{26}$ Instituto de Ciências do Mar, Universidade Federal do Ceará, Fortaleza, Brazil. ${ }^{27} \mathrm{CSIRO}$ Oceans and Atmosphere, Hobart, Tasmania, Australia. ${ }^{28}$ School of Aquatic and Fishery Sciences, University of Washington, Seattle, WA, USA. ${ }^{29}$ Biology Department, Woods Hole Oceanographic Institution, Woods Hole, MA, USA. ${ }^{30}$ Shark Research and Conservation Program, Cape Eleuthera Institute, Eleuthera, Bahamas. ${ }^{31}$ University of Exeter, Exeter, UK. ${ }^{32}$ South Atlantic Environmental Research Institute, Stanley, Falkland Islands. ${ }^{33}$ Department of Biological Sciences, The Guy Harvey Research Institute, Nova Southeastern University, Dania Beach, FL, USA. ${ }^{34}$ School of Natural Resources, University of Missouri, Columbia, MO, USA. ${ }^{35}$ Life and Environmental Sciences, University of Iceland, Reykjavik, Iceland. ${ }^{36}$ School of Marine Science and Policy, University of Delaware, Lewes, DE, USA. ${ }^{37}$ Massachusetts Division of Marine Fisheries, New Bedford, MA, USA. ${ }^{38}$ Marine Research Facility, Jeddah, Saudi Arabia. ${ }^{39} \mathrm{PSL}$, Labex CORAIL, CRIOBE USR3278 EPHE-CNRS-UPVD, Papetoai, French Polynesia. ${ }^{40} \mathrm{Agence}$ de Recherche pour la Biodiversité à la Réunion (ARBRE), Réunion, Marseille, France. ${ }^{41}$ Institut de Recherche pour le Développement, UMR 228 ESPACE-DEV, Réunion, Marseille, France. ${ }^{42}$ Save Our Seas Foundation-D'Arros Research Centre (SOSF-DRC), Geneva, Switzerland. ${ }^{43}$ South African Institute for Aquatic Biodiversity (SAIAB), Grahamstown, South Africa. ${ }^{44}$ Department of Fisheries Evaluation, Fisheries Research Division, Instituto de Fomento Pesquero (IFOP), Valparaíso, Chile. ${ }^{45}$ School of Biological, Earth and Environmental Sciences, University College Cork, Cork, Ireland. ${ }^{46} \mathrm{MaREI}$ Centre, Environmental Research Institute, University College Cork, Cork, Ireland. ${ }^{47}$ College of Science and Engineering, Flinders University, Adelaide, South Australia, Australia. ${ }^{48}$ Department of Conservation, Auckland, New Zealand. ${ }^{49}$ South African Institute for Aquatic Biodiversity, Geological Sciences, UKZN, Durban, South Africa. ${ }^{50}$ Direccion Parque Nacional Galapagos, Puerto Ayora, Galapagos, Ecuador. ${ }^{51}$ Australian Institute of Marine Science,
Indian Ocean Marine Research Centre (UWA), Crawley, Western Australia, Australia. ${ }^{52}$ Department of Fish and Wild life Conservation, Virginia Tech, Blacksburg, VA, USA. ${ }^{53}$ OCEARCH, Park City, UT, USA. ${ }^{54}$ Bedford Institute of Oceanography, Dartmouth, Nova Scotia, Canada. ${ }^{55}$ National Institute of Water and Atmospheric Research, Wellington, New Zealand. ${ }^{56}$ Beneath the Waves, Herndon, VA, USA. ${ }^{57}$ Rosenstiel School of Marine and Atmospheric Science, University of Miami, Miami, FL, USA. ${ }^{58}$ Oceans Research, Mossel Bay, South Africa. ${ }^{59}$ Department of Ichthyology and Fisheries Science, Rhodes University, Grahamstown, South Africa. ${ }^{60}$ SARDI Aquatic Sciences, Adelaide, South Australia, Australia. ${ }^{61}$ Zoological Society of London, London, UK. ${ }^{62}$ Galapagos Whale Shark Project, Puerto Ayora, Galapagos, Ecuador. ${ }^{63}$ Griffith Centre for Coastal Management, Griffith University School of Engineering, Griffith University, Gold Coast, Queensland, Australia. ${ }^{64} \mathrm{Bimini}$ Biological Field Station, South Bimini, Bahamas. ${ }^{65}$ Smithsonian Tropical Research Institute, Panama City, Panama. ${ }^{66}$ Leonard and Jayne Abess Center for Ecosystem Science and Policy, University of Miami, Coral Gables, FL, USA. ${ }^{67}$ Galapagos Science Center, San Cristobal, Galapagos, Ecuador. ${ }^{68}$ Universidad San Francisco de Quito, Quito, Ecuador. ${ }^{69}$ Blue Water Marine Research, Tutukaka, New Zealand. ${ }^{70}$ University of Queensland, Brisbane, Queensland, Australia. ${ }^{71}$ Microwave Telemetry, Columbia, MD, USA. ${ }^{72}$ Pelagios-Kakunja, La Paz, Mexico. ${ }^{73}$ Mote Marine Laboratory, Center for Shark Research, Sarasota, FL, USA. ${ }^{74}$ Biological Sciences, University of Windsor, Windsor, Ontario, Canada. ${ }^{75}$ Cape Research and Diver Development, Simon's Town, South Africa. ${ }^{76}$ Institute of Zoology, Zoological Society of London, London, UK. ${ }^{77}$ Centre for Sustainable Aquatic Ecosystems, Harry Butler Institute, Murdoch University, Perth, Western Australia, Australia. ${ }^{78}$ Dyer Island Conservation Trust, Western Cape, South Africa. ${ }^{79}$ Blue Wilderness Research Unit, Scottburgh, South Africa. ${ }^{80}$ University of California Davis, Davis, CA, USA. ${ }^{81}$ Cape Research Centre, South African National Parks, Steenberg, South Africa. ${ }^{82}$ Shark Spotters, Fish Hoek, South Africa. ${ }^{83}$ Institute for Communities and Wild life in Africa, Department of Biological Sciences, University of Cape Town, Rondebosch, South Africa. ${ }^{84}$ Western Cape Department of Agriculture, Veterinary Services, Elsenburg, South Africa. ${ }^{85}$ Departamento de Biologia Marinha, Universidade Federal Fluminense (UFF), Niterói, Brazil. ${ }^{86}$ Department of Zoology, University of Cambridge, Cambridge, UK. ${ }^{87}$ Atlantic White Shark Conservancy, Chatham, MA, USA. ${ }^{88}$ Fisheries and Aquaculture Centre, Institute for Marine and Antarctic Studies, University of Tasmania, Hobart, Tasmania, Australia. ${ }^{89}$ Pontificia Universidad Católica del Ecuador Sede Manabi, Portoviejo, Ecuador. ${ }^{90}$ Marine Megafauna Foundation, Truckee, CA, USA. ${ }^{91}$ Conservation and Fisheries Department, Ascension Island Government, Georgetown, Ascension Island, UK. ${ }^{92}$ Marine Conservation Society Seychelles, Victoria, Seychelles. ${ }^{93} \mathrm{CORDIO}$, East Africa, Mombasa, Kenya. ${ }^{94}$ Upwell, Monterey, CA, USA. ${ }^{95}$ Department of Zoology and Institute for Coastal and Marine Research, Nelson Mandela University, Port Elizabeth, South Africa. ${ }^{96}$ National Institute of Polar Research, Tachikawa, Tokyo, Japan. ${ }^{97}$ SOKENDAI (The Graduate University for Advanced Studies), Tachikawa, Tokyo, Japan. ${ }^{98}$ Centre for Ecology and Conservation, University of Exeter, Penryn, UK. ${ }^{99}$ Department of Biological Sciences, University of Rhode Island, Kingston, RI, USA. ${ }^{100}$ Department of Oceanography and Environment, Fisheries Research Division, Instituto de Fomento Pesquero (IFOP), Valparaíso, Chile. ${ }^{101}$ Department of Biological Sciences, Macquarie University, Sydney, New South Wales, Australia. ${ }^{102}$ School of Life and Environmental Sciences, Deakin University, Geelong, Victoria, Australia. ${ }^{103} \mathrm{AZTI}$ - Marine Research, Pasaia, Spain. ${ }^{104}$ IKERBASQUE, Basque Foundation for Science, Bilbao, Spain. ${ }^{105}$ Instituto de Fisica Interdisciplinar y Sistemas Complejos, Consejo Superior de Investigaciones Cientificas, University of the Balearic Islands, Palma de Mallorca, Spain. ${ }^{106}$ Wildlife Conservation Research Unit, Department of Zoology, University of Oxford, Tubney, UK. ${ }^{107}$ Ocean and Earth Science, National Oceanography Centre Southampton, University of Southampton Southampton, UK. ${ }^{108}$ Centre for Biological Sciences, University of Southampton, Southampton, UK. ${ }^{凶}$ e-mail: dws@mba.ac.uk 


\section{Matters arising}

Extended Data Table 1 | Global and regional drivers of FEl hotspots

\begin{tabular}{|l|l|l|l|l|l|l|}
\hline Ocean & $\begin{array}{l}\text { Shark } \\
\text { hotspots in } \\
\text { FEI } \\
\text { hotspots } \\
\text { (\%) }\end{array}$ & $\begin{array}{l}\text { High fishing } \\
\text { effort in FEI } \\
\text { hotspots } \\
\text { (\%) }\end{array}$ & $\begin{array}{l}\text { Shark } \\
\text { hotspots \& } \\
\text { High fishing } \\
\text { effort in FEI } \\
\text { hotspots } \\
\text { (\%) }\end{array}$ & $\begin{array}{l}\text { Neither } \\
\text { shark } \\
\text { hotspots } \\
\text { nor high } \\
\text { fishing } \\
\text { effort in FEI } \\
\text { hotspots } \\
\text { (\%) }\end{array}$ & $\begin{array}{l}\text { FEI } \\
\text { hotspots } \\
\text { overlap } \\
\text { shark } \\
\text { hotspots } \\
\text { (\%) }\end{array}$ & $\begin{array}{l}\text { FEI } \\
\text { hotspots } \\
\text { overlap } \\
\text { high fishing } \\
\text { effort (\%) }\end{array}$ \\
\hline Global & 17.2 & 42.1 & 38.8 & 1.9 & 56.0 & 80.9 \\
\hline N Atlantic & 16.7 & 43.9 & 37.6 & 1.8 & 54.3 & 81.5 \\
\hline Oceania & 8.8 & 52.7 & 37.4 & 1.1 & 46.2 & 90.1 \\
\hline SW Indian & 11.7 & 53.2 & 34.2 & 0.9 & 45.9 & 87.4 \\
\hline NE Pacific & 31.0 & 18.6 & 46.5 & 3.9 & 77.5 & 65.1 \\
\hline
\end{tabular}

Values given in the first four columns are the percentages of grid cells of shark hotspots ( $>75$ th percentile of relative density) and/or high fishing effort (>50th percentile of mean fishing days)

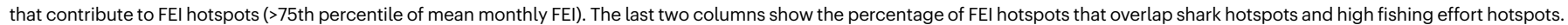


Extended Data Table 2 | Examples of global and regional drivers of FEl hotspots for individual shark species

\begin{tabular}{|l|l|l|l|l|l|l|l|}
\hline Species & Ocean & $\begin{array}{l}\text { Shark } \\
\text { hotspots } \\
\text { in FEI } \\
\text { hotspots } \\
\text { (\%) }\end{array}$ & $\begin{array}{l}\text { High fishing } \\
\text { effort in FEI } \\
\text { hotspots } \\
\text { (\%) }\end{array}$ & $\begin{array}{l}\text { Shark } \\
\text { hotspots \& } \\
\text { high fishing } \\
\text { effort in FEI } \\
\text { hotspots } \\
\text { (\%) }\end{array}$ & $\begin{array}{l}\text { Neither } \\
\text { shark } \\
\text { hotspots } \\
\text { nor high } \\
\text { fishing } \\
\text { effort in } \\
\text { FEI } \\
\text { hotspots } \\
\text { (\%) }\end{array}$ & $\begin{array}{l}\text { FEI } \\
\text { hotspots } \\
\text { overlap } \\
\text { shark } \\
\text { hotspots } \\
\text { (\%) }\end{array}$ & $\begin{array}{l}\text { FEI } \\
\text { hotspots } \\
\text { overlap } \\
\text { high } \\
\text { fishing } \\
\text { effort } \\
\text { (\%) }\end{array}$ \\
\hline Blue & Global & 8.6 & 38.8 & 50.2 & 2.4 & 58.7 & 89.0 \\
\hline & N Atlantic & 7.6 & 40.4 & 49.7 & 2.3 & 57.3 & 90.1 \\
\hline & Oceania & 0.0 & 66.7 & 33.3 & 0.0 & 33.3 & 100.0 \\
\hline & SW Indian & - & - & - & - & - & - \\
\hline White & NE Pacific & 33.3 & 6.7 & 53.3 & 6.7 & 86.7 & 60.0 \\
\hline & Global & 17.0 & 28.6 & 53.3 & 1.2 & 70.3 & 81.9 \\
\hline & N Atlantic & 31.8 & 20.5 & 47.7 & 0.0 & 79.5 & 68.2 \\
\hline & Oceania & 6.3 & 34.4 & 56.3 & 3.1 & 62.5 & 90.6 \\
\hline & SW Indian & 11.8 & 41.8 & 45.5 & 0.9 & 57.3 & 87.3 \\
\hline & NE Pacific & 20.5 & 11.0 & 67.1 & 1.4 & 87.7 & 78.1 \\
\hline
\end{tabular}

Values given in the first four columns are the percentages of grid cells of shark hotspots ( $>75$ th percentile of relative density) and/or high fishing effort (>50th percentile of mean fishing days) that contribute to FEI hotspots ( $>75$ th percentile of mean monthly FEI). The last two columns show the percentage of FEl hotspots that overlap shark hotspots and high fishing effort hotspots. Blue, blue shark (Prionace glauca); white, white shark (Carcharodon carcharias). No blue sharks were tracked in the southwest Indian Ocean. 


\section{Matters arising}

Extended Data Table 3 | Spatial refuge of pelagic sharks in ABNJs

\begin{tabular}{|l|c|c|c|}
\hline & \multicolumn{2}{|c|}{ No. of grid cells } & Potential refuge \\
\hline $\begin{array}{l}\text { Areas Beyond } \\
\begin{array}{l}\text { National } \\
\text { Jurisdiction } \\
\text { (ABN) }\end{array}\end{array}$ & $\begin{array}{c}\text { Shark relative } \\
\text { density hotspot }\end{array}$ & $\begin{array}{c}\text { Shark relative } \\
\text { density hotspot with } \\
\text { no AlS longline } \\
\text { fishing effort }\end{array}$ & $\begin{array}{c}\text { Percentage of shark hotspots } \\
\text { with no AIS longline fishing } \\
\text { effort }\end{array}$ \\
\hline Global & 1187 & 437 & 36.8 \\
\hline N Atlantic & 400 & 79 & 19.8 \\
\hline Oceania & 57 & 24 & 42.1 \\
\hline SW Indian & 61 & 8 & 13.1 \\
\hline NE Pacific & 651 & 324 & 49.8 \\
\hline
\end{tabular}


Extended Data Table 4 | Comparison of spatial refuge estimated with AIS data 2012-2016 and 2012-2018

\begin{tabular}{|l|c|c|c|}
\hline $\begin{array}{l}\text { Areas Beyond } \\
\text { National } \\
\text { (ABNisdiction }\end{array}$ & $\begin{array}{c}\text { Refuge estimated with } \\
\text { GFW 2012-16 AIS data }\end{array}$ & $\begin{array}{c}\text { Refuge estimated with } \\
\text { GFW 2012-18 AIS data }\end{array}$ & $\begin{array}{c}\text { Difference (percentage } \\
\text { refuge in 2012-18 minus } \\
\text { 2012-16) }\end{array}$ \\
\hline Global & $\begin{array}{c}\text { Percentage of shark } \\
\text { hotspots with no AIS } \\
\text { longline fishing effort }\end{array}$ & $\begin{array}{c}\text { Percentage of shark } \\
\text { hotspots with no AIS } \\
\text { longline fishing effort }\end{array}$ & \\
\hline N Atlantic & 36.8 & 23.1 & -13.7 \\
\hline Oceania & 19.8 & 5.8 & -14.0 \\
\hline SW Indian & 42.1 & 37.5 & -4.6 \\
\hline NE Pacific & 13.1 & 8.2 & -4.9 \\
\hline
\end{tabular}

The Global Fishing Watch 2012-2016 AIS longline fishing effort data we used in our paper1 have been further developed to include additional years (2017 and 2018 ) with a higher number of AIS satellites operating and vessels reporting, resulting in substantially more vessel locations for analysis (https://globalfishingwatch.org/). The percentage spatial refuge for sharks in ABNJs decreased to less than a quarter of shark relative density hotspots when more recent fishing effort data were included. 


\section{Author Queries}

Journal: Nature

Paper: s41586-021-03397-3

Title:Reply to: Shark mortality cannot be assessed by fishery overlap alone

\section{AUTHOR:}

The following queries have arisen during the editing of your manuscript. Please answer by making the requisite corrections directly in thee.proofing tool rather than marking them up on thePDF. This will ensure that your correctionsare incorporated accurately and that your paper is published as quickly as possible.

\begin{tabular}{|c|c|}
\hline $\begin{array}{l}\text { Query } \\
\text { Reference }\end{array}$ & Reference \\
\hline Q1 & $\begin{array}{l}\text { Please check your article carefully, coordinate with any co-authors and enter all final edits clearly in the } \\
\text { eproof, remembering to save frequently. Once corrections are submitted, we cannot routinely make } \\
\text { further changes to the article. }\end{array}$ \\
\hline Q2 & $\begin{array}{l}\text { Note that the eproof should be amended in only one browser window at any one time; otherwise } \\
\text { changes will be overwritten. }\end{array}$ \\
\hline Q3 & $\begin{array}{l}\text { Author surnames have been highlighted. Please check these carefully and adjust if the first name or } \\
\text { surname is marked up incorrectly. Note that changes here will affect indexing of your article in public } \\
\text { repositories such as PubMed. Also, carefully check the spelling and numbering of all author names } \\
\text { and affiliations, and the corresponding email address(es). }\end{array}$ \\
\hline Q4 & $\begin{array}{l}\text { You cannot alter accepted Supplementary Information files except for critical changes to scientific } \\
\text { content. If you do resupply any files, please also provide a brief (but complete) list of changes. If these } \\
\text { are not considered scientific changes, any altered Supplementary files will not be used, only the } \\
\text { originally accepted version will be published. }\end{array}$ \\
\hline Q5 & $\begin{array}{l}\text { When you receive the eproof link, please check that the display items are as follows (ms no: 2020-01- } \\
\text { 01184): Figs (black and white); } 2 \text { (colour); Tables: None; Boxes: None; Extended Data display items: } \\
\text { 1-4; SI (including reporting summary): yes. The eproof contains the main-text figures edited by us } \\
\text { and (if present) the Extended Data items (unedited except for the legends) and the Supplementary } \\
\text { Information (unedited). Please note that the eproof should be amended in only one browser window } \\
\text { at any one time, otherwise changes will be overwritten. Please check the edits to all main-text figures } \\
\text { very carefully, and ensure that any error bars in the figures are defined in the figure legends. Extended } \\
\text { Data items may be revised only if there are errors in the original submissions. If you need to revise any } \\
\text { Extended Data items please upload these files when you submit your corrections to this preproof. }\end{array}$ \\
\hline
\end{tabular}




\section{Reporting Summary}

Nature Research wishes to improve the reproducibility of the work that we publish. This form provides structure for consistency and transparency in reporting. For further information on Nature Research policies, see our Editorial Policies and the Editorial Policy Checklist.

\section{Statistics}

For all statistical analyses, confirm that the following items are present in the figure legend, table legend, main text, or Methods section.

n/a Confirmed

$\square$ The exact sample size $(n)$ for each experimental group/condition, given as a discrete number and unit of measurement

$\square$ \ A statement on whether measurements were taken from distinct samples or whether the same sample was measured repeatedly

The statistical test(s) used AND whether they are one- or two-sided

$\square$ Only common tests should be described solely by name; describe more complex techniques in the Methods section.

$\square$ \ A description of all covariates tested

$\square$ \A description of any assumptions or corrections, such as tests of normality and adjustment for multiple comparisons

$\square$ A full description of the statistical parameters including central tendency (e.g. means) or other basic estimates (e.g. regression coefficient)

AND variation (e.g. standard deviation) or associated estimates of uncertainty (e.g. confidence intervals)

$\square$ For null hypothesis testing, the test statistic (e.g. $F, t, r$ ) with confidence intervals, effect sizes, degrees of freedom and $P$ value noted

Give $P$ values as exact values whenever suitable.

Х $\square$ For Bayesian analysis, information on the choice of priors and Markov chain Monte Carlo settings

Х $\square$ For hierarchical and complex designs, identification of the appropriate level for tests and full reporting of outcomes

$\triangle \square$ Estimates of effect sizes (e.g. Cohen's $d$, Pearson's $r$ ), indicating how they were calculated

Our web collection on statistics for biologists contains articles on many of the points above.

\section{Software and code}

Policy information about availability of computer code

Data collection No data collection software was used.

Data analysis All analyses described were undertaken in $\mathrm{R}$.

For manuscripts utilizing custom algorithms or software that are central to the research but not yet described in published literature, software must be made available to editors and reviewers. We strongly encourage code deposition in a community repository (e.g. GitHub). See the Nature Research guidelines for submitting code \& software for further information.

\section{Data}

Policy information about availability of data

All manuscripts must include a data availability statement. This statement should provide the following information, where applicable:

- Accession codes, unique identifiers, or web links for publicly available datasets

- A list of figures that have associated raw data

- A description of any restrictions on data availability

Data used in linear regression modelling are available on GitHub (https://github.com/GlobalSharkMovement/GlobalSpatialRisk/derived_data/). Data and source code used for preparing figure maps (shark relative spatial density, longline-fishing effort and shark-longline-fishing overlap and FEI) are available on GitHub (https://github.com/GlobalSharkMovement/GlobalSpatialRisk). 


\section{Field-specific reporting}

Please select the one below that is the best fit for your research. If you are not sure, read the appropriate sections before making your selection.

Life sciences $\quad \square$ Behavioural \& social sciences $\quad \square$ Ecological, evolutionary \& environmental sciences

For a reference copy of the document with all sections, see nature.com/documents/nr-reporting-summary-flat.pdf

\section{Ecological, evolutionary \& environmental sciences study design}

All studies must disclose on these points even when the disclosure is negative.

Study description

This study is a Reply to a Matters Arising comment on our original paper. To answer the points raised we re-plotted some of the original data from our paper which are fully described in figure and table legends and in our original paper. We carried out new analyses using general linear regression modelling to examine relationships between shark catch per unit effort and fishing exposure risk (FEI), number of longline sets and fishing effort.

Research sample

In this Reply, pelagic shark catch in biomass (kg) retained (recorded in skipper's logbooks) by the Spanish pelagic longline fleet in the North Atlantic was used. Catch data were available and were included for the following tracked sharks: blue shark (Prionace glauca), shortfin mako (Isurus oxyrinchus), longfin mako (I. paucus), tiger shark (Galeocerdo cuiver), white shark (Carcharodon carcharias), porbeagle shark (Lamna nasus), silky shark (Carcharhinus falciformis), smooth hammerhead shark (Sphyrna zygaena), bigeye thresher shark (Alopias superciliosus), copper shark (Carcharhinus brachyurus) and the sandbar shark (C. plumbeus).

Sampling strategy Shark catch data recorded by the Spanish longline fleet in the North Atlantic were made available by the Spanish authorities after data collection so we had no control over the sampling strategy.

Data collection

Shark catch data recorded by the Spanish longline fishing fleet in the North Atlantic were made available by the Spanish authorities.

Timing and spatial scale

Shark catch data were available from the Spanish longline fishing fleet in the North Atlantic between January 2013 and November 2017.

Data exclusions

In this Reply, no data were excluded except when running sensitivity analysis for linear regression modelling. Here, models were compared using the Akaike and Bayesian information criterion (AIC) and the models strength of evidence assessed using the AIC weights (WAIC). We then used $\mathrm{r}^{\wedge} 2$ to quantify the models goodness of fit, and repeated the same procedure when randomly removing $1,5,10$ and $25 \%$ of the data.

Reproducibility

No experiments as such were conducted, rather our data are based on satellite tracked movements of individual pelagic sharks and fishing vessels, and shark catch data from fisheries.

Randomization Randomization procedures were used when removing 1, 5, 10 and $25 \%$ of the data for sensitivity analysis using linear regression modelling. Methods are fully described in the Reply and Supplementary Information files.

Blinding

Blinding is not relevant to this type of study because our original data were based on movements of wild animals and fishing vessels.

Did the study involve field work? $\square$ Yes $\$ No

\section{Reporting for specific materials, systems and methods}

We require information from authors about some types of materials, experimental systems and methods used in many studies. Here, indicate whether each material, system or method listed is relevant to your study. If you are not sure if a list item applies to your research, read the appropriate section before selecting a response.

\begin{tabular}{|c|c|}
\hline$n / a$ & Involved in the study \\
\hline Х & Antibodies \\
\hline Х & Eukaryotic cell lines \\
\hline$\bigotimes$ & Palaeontology and archaeology \\
\hline Х & Animals and other organisms \\
\hline Х & Human research participants \\
\hline 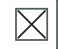 & Clinical data \\
\hline Х & Dual use research of concern \\
\hline
\end{tabular}

\begin{tabular}{l|l} 
Methods \\
\hline n/a & Involved in the study \\
$\bigotimes$ & $\square$ ChIP-seq \\
$\square$ & $\square$ Flow cytometry \\
$\square$ & $\square$ MRI-based neuroimaging
\end{tabular}

